\title{
Impact of COVID-19 on Internet Traffic in Nigeria
}

\author{
Bamidele Moses Kuboye \\ Department of Information Technology, Federal University of Technology, Akure, Ondo State, Nigeria \\ Email: bmkuboye@futa.edu.ng
}

How to cite this paper: Kuboye, B.M. (2022) Impact of COVID-19 on Internet Traffic in Nigeria. Communications and Network, 14, 36-44.

https://doi.org/10.4236/cn.2022.141004

Received: January 6, 2022

Accepted: February 7, 2022

Published: February 10, 2022

Copyright $\odot 2022$ by author(s) and Scientific Research Publishing Inc. This work is licensed under the Creative Commons Attribution International License (CC BY 4.0).

http://creativecommons.org/licenses/by/4.0/

\begin{abstract}
In the course of the outbreak of COVID-19, the Nigerian society adopted digital life as an alternative to physical interaction so as to keep afloat in the period of the lockdown. This option brought about a lot of changes especially in the usage of communication facilities. Many Nigerians that are not willing to have Internet connectivity had no option than to accept the reality on ground. This work examines the related literatures within and outside Nigeria. Thereafter, it examined the usage level and satisfaction of the users through questionnaires administering to the subscribers of different cellular networks available. The questionnaires were administered in Akure to the cellular subscribers of MTN, GLO, Airtel and 9mobile randomly. Afterwards, the data were analyzed and discussion of the results of each component of the questionnaires was done. The study revealed that MTN subscribers are more and most respondents are just using 4G services within 1 - 6 months durations. Also, the studies established that those respondents always on $4 \mathrm{G}$ Services are more than any other class in a day. Thus, this work established that COVID-19 pandemic brought changes to the daily activities, thus, a shift to digital life among the subscribers.
\end{abstract}

\section{Keywords}

COVID-19, GSMA, 4G, LTE, Cellular

\section{Introduction}

The outbreak of corona virus (COVID-19) affects every aspect of life and leveled everyone on an equal scale. There were temporary closures of restaurants, malls, shops, gyms, schools, institutions, and so on. Governments all over the world adopted curfews, social distancing, facemasks and some of other measures to reduce the spread of this deadly virus, hence, directly affected the happenings in 
mobile sphere. In Nigeria, the President of the Federal Republic of Nigeria on 29th March, 2020 in a nationwide broadcast restricts movement in Lagos, Ogun and the Federal Capital Territory (FCT) Abuja [1]. Similar measures have been taken previously by several State governors and the Minister of the FCT.

People interacted more with their mobile devices to keep up with the news, fill the gaps in their routine and social life during the period of staying at home. MMAGlobal declared in the period of lockdown, the time spent on mobile daily rose from 4 hours 5 hours [2]. The experts in round table on this happening organized by International Telecommunication Union (ITU) agreed that these actions had led to a spike in telecommunication network usage, and thus had increased the overall Internet [3]. Furthermore, right from the middle of February 2020 in China, the weekly average downloads almost doubled compared to that of 2019 according to MMAGlobal [4]. The most mobile applications popularly used during this period were Huawei Cloud WeLink, DingTalk and ZOOM for education, conferences, and meetings. Furthermore, game and video applications using YouTube, Netflix, Hulu and so on increased significantly during this period, thus, affecting the usage of mobile networks capabilities. Table 1 gives some examples of the increase in traffic compiled from telecommunication operators [3]. The economic expert's roundtable participants on the impact of COVID-19 digital infrastructure organized by ITU agreed that overall telecommunication networks have exhibited consistent resilience in the face of the changes in traffic. They also agreed that Wi-Fi capacity was stressed by an 80 percent increase in PC uploads to cloud platforms with additional peaks from video conference calls.

GSMA also put up a paper where it was declared that almost half of the population of the world use mobile internet and those living outside the covered areas

Table 1. Internet Usage increase triggered by COVID-19 [3].

\begin{tabular}{|c|c|c|c|}
\hline Area & Service Provider & Area of usage percent increase & Source \\
\hline \multirow{4}{*}{ Telecommunication traffic } & AT \& T (US) & Core Network traffic (22\%) & $\mathrm{AT} \& \mathrm{~T}$ \\
\hline & British Telecom (UK) & Fixed network traffic ( $60 \%$ on weekdays) & British Telecom \\
\hline & Telecom Italia (Italy) & Internet Traffic (70\%) & Telecom Italia \\
\hline & Vodafone & Mobile data traffic in Italy and Spain & Vodafone \\
\hline \multirow{5}{*}{ Over The Top } & & Facebook Messenger (50\%) & Facebook \\
\hline & Facebook & WhatsApp (Overall: 50\%; Spain: 76\%) & WhatsApp \\
\hline & & Video calling $(100 \%)$ & Facebook \\
\hline & Netflix & Subscriber base ( $9.6 \%$ or 16 million) & Netflix \\
\hline & E-commerce(Mexico) & Number of Users & Competitive Intelligence \\
\hline \multirow{3}{*}{ Video Conference } & Zoom & Daily usage (300\%) & JP Morgan \\
\hline & Cisco Webex & Subscribers (33\%) & Cisco \\
\hline & Teams (Italy) & Monthly users (775\%) & Microsoft \\
\hline
\end{tabular}


of mobile broadband networks continues to reduce as a result of the upgrades of $2 \mathrm{G}$ sites to $3 \mathrm{G}$ and $4 \mathrm{G}$ especially Sub-Saharan Africa [5]. In fact, It was declared that the bulk of mobile connections all over the world now use $4 \mathrm{G}$. Though, it was established that the rural-urban and gender gaps in mobile internet use remain substantial but are narrowing. Also, the Smartphones have become more affordable but they remain too expensive to subscribers in many Low and middle-income countries (LMICs). Also, the affordability of Mobile data is still a major challenge for the poor and illiterates in society even though they are increasingly available in sub-Saharan Africa. The China Academy of Information and Communications Technology (CAICT), The GSMA and 5G Applications Industry Array (5GAIA) white paper on "Mobile Industry Response to in China stated that Mobile operators in China have made all efforts since the outbreak of COVID-19 to communication services for mission-critical entity such as hospitals and government agencies. They had strengthened the coverage and application of $4 \mathrm{G} / 5 \mathrm{G}$ networks to provide the smooth operations to emergencies such as telemedicine, health professionals, remote consultation and patients. According to the paper, China Mobile and China Unicom constructed three 4G/5G sites and five $4 \mathrm{G} / 5 \mathrm{G}$ sites respectively within 30 hours. The high-quality $4 \mathrm{G} / 5 \mathrm{G}$ networks have ensured smooth and uninterrupted communication services in China during the COVID-19 pandemic [6]

Forest Interactive [7] presented that due to imposed lockdown by governments the telecommunications sector saw a massive spike in data traffic and increased use of broadband services as more people relied on connected devices and IoT devices throughout 2020. Considering the KPMG-UK report, Europe saw a spike in internet traffic, as high as $70 \%$ within 2 - 3 weeks during the peak of lockdown and isolation. As a result, the telecommunications sector continues to play a critical role in supporting governments, consumers, and businesses for daily running [7]. Rodríguez-Castelán et al. [8] carried out analysis on Mobile Internet adoption in West Africa, their results show two ways process of adoption. They are the households living in an area with $3 \mathrm{G}$ coverage and the ones that decide to adopt mobile broadband specification. Also, two main constraints were identified to this adoption, the low levels of household consumption and the high price of mobile internet services.

GSMA stated that Nigeria has the most improved Mobile Connectivity Index in 2019 among country in Sub-Saharan Africa and the seventh most improved globally [5]. GSMA stated that 3G coverage Infrastructure was 78\% in 2019 and $45 \%$ coverage have been accomplished by the operators since the first rollout of $4 \mathrm{G}$ network in 2016. The improvements in coverage especially in 3G are partly driven by the deployment of UMTS-900, which shows, operators reuse part of their $2 \mathrm{G}$ spectrum in $900 \mathrm{MHz}$ to deploy $3 \mathrm{G}$ thus reduce the cost. Enhanced $4 \mathrm{G}$ coverage has brought improved network download and upload speeds and lower latencies. GSMA declared that Nigeria has one of the most affordable handset costs in the world and mobile charges have become more affordable. Due to this 
progress, mobile internet penetration has doubled in six years from 16\% in 2014 to $32 \%$ in 2019 with about 7.5 million new mobile internet subscribers in the country. In spite of the progress, about $20 \%$ of population currently uncovered, a great rural-urban gap in internet use and gender gap. Also, illiteracy of a substantial quota of adults as well as skills labour in the country are part of barriers to using mobile internet [5]

Maikomo et al. [9], examined the sudden digital migration in Nigeria and identifies the factors that facilitated the process. It was established that because of the lockdown some areas of economy moved completely to e-marketing, e-learning, virtual meetings and conferences. The social media world was full of advertisements of all kinds. However, some constraints like GSM network and Internet service, government unpreparedness, lack of electricity, as well as, illiteracy were identified. The study concludes that effective digitization in Nigeria requires a holistic approach. Adumah et al. [10] examined the Perception of medical students toward online lectures during COVID-19 outbreak in a Nigerian university. They established that the closures of educational institutions in Nigeria due to the advent of COVID-19 pandemic necessitated the adoption of online lectures. Their studies were conducted among the clinical students of the Babcock University, Ilisan, Ogun State, Nigeria, who were receiving online lectures during the COVID-19 pandemic outbreak. This has prompted the use of online digital educational platforms such as Zoom, Edmodo, and Google Classroom to conduct lectures and examinations for students. The outcome of the study showed that Online lectures can be an outstanding substitute to the routine class lectures if planned well. Afolabi et al. [11] examined the Impact of COVID-19 Pandemic on Haemodialysis care at a tertiary centre in south east Nigeria. The study established that due to COVID-19 lockdown there was a reduction in the number of haemodialysis cases, increments in haemodialysis cost, materials for the procedure were scarce, and therefore, there was a minor disruption of haemodialysis care. It also observed that there was a positive effect on haemodialysis care as a result of an improvement in infection control practice at the dialysis unit.

KPMG [12] examined COVID-19 and the Nigerian Telecommunication, Media and Technology (TMT) Sector. It was stated that the Nigerian telecoms industry appears to be experiencing a boom like its counterpart in the developed economies despite the pandemic. As a result of the lockdown, schools and major organizations have also had to move to online platforms. According to the paper, the Nigerian Communications Commission (NCC) alluded to the increase in the volume of voice and data traffic over the past few weeks and efforts of the telecommunication companies to the installation of more fiber optics to ensure unhindered communications. MTN Nigeria one of the cellular provider released its unaudited financial result for the first quarter of 2020 that showed increased data revenue by $32.4 \%$. Also, the digital platforms that have been deployed by some government agencies such as the Corporate Affairs 
Commission (CAC), Federal Inland Revenue Service (FIRS), and other regulatory agencies have been widely applauded by stakeholders because it has reduce the risk of exposing them to health hazards associated with physical movement. However, it was concluded that organizations will need to proactively plan and re-strategize in order to prepare for the new reality and remain relevant.

However, due to the effect of COVID-19 and the lockdown imposed by government, vast majority of subscribers now relied on online communications. The telecommunications sector saw a great growth in data traffic and broadband services use as more people relied on connected devices [3]. Also, the operators have been proactive in taking instant measures to sustain connectivity due to the downturn of the economy on subscribers such as increasing data allowances or bonuses, reducing the prices of mobile data and making data free in certain part the hours to subscribers that bought data. Despite all these incentives, this research is directed towards the ascertaining the satisfaction of subscribers considering the capability of Nigeria cellular telecommunication connectivity. The work was carried out to survey the cellular networks subscribers' satisfaction using the city of Akure as a case study.

\section{Methodology}

The Long Term Evolution (LTE) Fourth Generation (4G) mobile communication is one of the latest telecommunication developments in Nigeria. Despite the challenges in operations, the service-providers claimed to be successful and effective in $4 \mathrm{G}$ operations. This work measures the customers' satisfaction level of using LTE $4 \mathrm{G}$ by cross-examine the subscribers of this service to ascertain the service provider's claim. In the bid to access the performance of LTE network in Nigeria, data on broadband performance were collected using survey research method by administering questionnaires to the subscribers of the cellular network in Akure, Ondo State, Nigeria. In order to achieve this goal, this study tries to identify and cross-examined various factors that influence customer satisfaction and dissatisfaction in using $4 \mathrm{G}$ mobile technology.

The key informants' responses were added in the discussion of findings. A total of one hundred and twenty (164) questionnaires were distributed to residents within Akure in which only one hundred and twenty (120) were recovered. The participated broadband subscribers comprised of civil servants, lecturers, politicians, unemployed graduates, traders, doctors, engineers and students. The items on the questionnaires include Gender type, type of system used either PC or Smartphones, the Network provider service in use, how frequently do they have access to $4 \mathrm{G}$ Services, how long have they been using the $4 \mathrm{G}$ services, the mobile operator used for accessing $4 \mathrm{G}$ services and how important is $4 \mathrm{G}$ Services. Thereafter, the data from the questionnaire were analyzed and the opinion-surveyed have shown concerns over the internet speed, network availability, customer services and the internet package of $4 \mathrm{G}$. 


\section{Results and Discussions}

The percentage of male using either of the devices in Table 2 is $52.5 \%$ and female to be $47.5 \%$. However, the number of male using smartphone and Personal Computer (PC) are 32 and 31 while the number of female using smartphone and PC are 24 and 33 respectively. Furthermore, the total for those using Smartphone and PC are 56 and 64 respectively. Those having PC are more than that of people using Smartphone probably because of its necessity to their work especially the students and office workers as Akure is the capital city of Ondo state in Nigeria where many higher institutions and government offices were located. Thus, this corroborates with the write-up by Ajumogobia and Okeke, [1]. Table 3 shows the percentage of male using either of the networks to be $52.5 \%$ and that of female is $47.5 \%$. However, the percentage of male users by operators MTN, GLO, AIRTEL, 9MOBILE, are 23.3\%, 12.5\%, 15.0\%, $1.7 \%$ respectively, while their female counterpart are 21.7\%, 15.0\%, 10.0\%, 0.8\%. Furthermore, the totals for MTN, GLO, AIRTEL, 9MOBILE are 54, 33, 30, and 3 respectively. However, those subscribers with MTN are more than that of people using other networks which may be because of its service availability which will amount to service satisfaction, otherwise, they might have moved to other networks since there are other options available [12].

The number of male users in 1 - 6 months, 6 months - 1 years, 1 - 2 years, more than 2 years are $19,13,13$, and 18 while that of female users in the same period 14, 14, 16, and 13 accordingly as shown in Table 4. Also, their totals are $33,27,29$, and 31 . Those that are just using $4 \mathrm{G}$ services within 1 - 6 moths are more than the other durations probably because of covid-19 lockdown and change of mode of interaction from physical to virtual. During the period most

Table 2. Type of device used.

\begin{tabular}{cccccc}
\hline Variables & Smartphones & $\begin{array}{c}\text { Personal } \\
\text { Computer (PC) }\end{array}$ & Total & $\begin{array}{c}\text { Percentage } \\
(\%)\end{array}$ & $\begin{array}{c}\text { Cumulative } \\
\text { percentage (\%) }\end{array}$ \\
\hline Male & 32 & 31 & 63 & 52.5 & 52.5 \\
Female & 34 & 33 & 57 & 47.5 & 100 \\
Total & 56 & 64 & 120 & & \\
\hline
\end{tabular}

Table 3. Type of Cellular operator used.

\begin{tabular}{cccccccc}
\hline Variable & MTN & Glo & Airtel & 9mobile & Total & $\begin{array}{c}\text { Percentage } \\
(\%)\end{array}$ & $\begin{array}{c}\text { Cumulative } \\
\text { Percentage } \\
(\%)\end{array}$ \\
\hline Male & 28 & 15 & 18 & 2 & 63 & $52.5 \%$ & $52.5 \%$ \\
& $23.3 \%$ & $12.5 \%$ & $15.0 \%$ & $1.7 \%$ & & & 100 \\
Female & 26 & 18 & 12 & 1 & 57 & $47.5 \%$ & \\
Total & $21.7 \%$ & $15.0 \%$ & $10.0 \%$ & $0.8 \%$ & & & \\
\hline
\end{tabular}


meetings, conferences are virtual and even now hybrid methodology are being employed where some that do not have important presentations are enjoyed to join virtually as is done in weekly Federal executive meetings with the president of Nigeria [1] [13]. According to Table 5, the number of male frequently having access to $4 \mathrm{G}$ Services every now and then, and few times in a day according to the research are 32 and 31 respectively, while the number of female frequently having access to $4 \mathrm{G}$ Services every now and then, and few times in a day according to the research are 37 and 20 respectively. The sum of those frequently having access to $4 \mathrm{G}$ Services and fewer times in a day are 69 and 51 respectively. Those having access to $4 \mathrm{G}$ Services, every now and then, are more than that of people having access to $4 \mathrm{G}$ Services, few times in a day, probably because of services available. The results showed that people depend more on online services and information than before the covid-19 pandemic [9].

Considering Table 6, it is shown that the number of male using the following kind of $4 \mathrm{G}$ services like Internet, Multiple 4G services and Video Conferencing are 25,19 , and 19 respectively, while the number of female are $23,13,21$, and 57. Furthermore, the totals are 48,32 , and 40 respectively. Those using $4 \mathrm{G}$ Internet services are more than that of people using other kind of $4 \mathrm{G}$ services like WhatsApp, Telegram, YouTube, Zoom probably because as it had been established earlier in Table 2 that students and government office workers are more dependent

Table 4. GENDER * How long have you been using the $4 \mathrm{G}$ services?

\begin{tabular}{|c|c|c|c|c|c|c|c|}
\hline Variable & 1 - 6 months & $\begin{array}{l}6 \text { months } \\
\text { to } 1 \text { year }\end{array}$ & $\begin{array}{l}1-2 \\
\text { years }\end{array}$ & $\begin{array}{l}\text { More than } \\
2 \text { years }\end{array}$ & Total & $\begin{array}{c}\text { Percentage } \\
(\%)\end{array}$ & $\begin{array}{c}\text { Cumulative } \\
\text { Percentage (\%) }\end{array}$ \\
\hline Male & 19 & 13 & 13 & 18 & 63 & $52.5 \%$ & $52.5 \%$ \\
\hline Female & 14 & 14 & 16 & 13 & 57 & $47.5 \%$ & 100 \\
\hline Total & 33 & 27 & 29 & 31 & 120 & & \\
\hline
\end{tabular}

Table 5. GENDER * How frequently do you access to $4 \mathrm{G}$ Services?

\begin{tabular}{cccccc}
\hline Variables & $\begin{array}{c}\text { Every now } \\
\text { and then }\end{array}$ & $\begin{array}{c}\text { Few times } \\
\text { in a day }\end{array}$ & total & $\begin{array}{c}\text { Percentage } \\
(\%)\end{array}$ & $\begin{array}{c}\text { Cumulative } \\
\text { percentage (\%) }\end{array}$ \\
\hline Male & 32 & 31 & 63 & 52.5 & 52.5 \\
Female & 37 & 20 & 57 & 47.5 & 100 \\
Total & 69 & 51 & 120 & & \\
\hline
\end{tabular}

Table 6. GENDER * Which $4 \mathrm{G}$ services do you use?

\begin{tabular}{ccccccc}
\hline Variable & Internet & $\begin{array}{c}\text { Multiple } \\
\text { 4G services }\end{array}$ & $\begin{array}{c}\text { Video } \\
\text { Conferencing }\end{array}$ & Total & $\begin{array}{c}\text { Percentage } \\
\text { (\%) }\end{array}$ & $\begin{array}{c}\text { Cumulative } \\
\text { Percentage (\%) }\end{array}$ \\
\hline Male & 25 & 19 & 19 & 63 & $52.5 \%$ & $52.5 \%$ \\
Female & 23 & 13 & 21 & 57 & $47.5 \%$ & $100 \%$ \\
Total & 48 & 32 & 40 & 120 & & \\
\hline
\end{tabular}


Table 7. GENDER * How important is 4 G Services?

\begin{tabular}{ccccccc}
\hline Variable & Important & $\begin{array}{c}\text { Moderately } \\
\text { Important }\end{array}$ & $\begin{array}{c}\text { Extremely } \\
\text { Important }\end{array}$ & Total & $\begin{array}{c}\text { Percentage } \\
(\%)\end{array}$ & $\begin{array}{c}\text { Cumulative } \\
\text { Percentage (\%) }\end{array}$ \\
\hline Male & 15 & 12 & 36 & 63 & $52.5 \%$ & $52.5 \%$ \\
Female & 11 & 18 & 28 & 57 & $47.5 \%$ & $100 \%$ \\
Total & 26 & 30 & 64 & 120 & & \\
\hline
\end{tabular}

on Internet services for assignments, forwarding and documenting important information for future references [10]. Table 7 revealed the view of subscribers on how important $4 \mathrm{G}$ Services to them. According to the research, Important, Moderately Important, and Extremely Important are 15, 12 and 36 while the female showing their view on how important is $4 \mathrm{G}$ Services are 11,18 , and 28 respectively. The totals are 26,30 , and 64 respectively. The survey results in this table also corroborates to the outcome of Table 6 that users depend more on online services now than before for their daily activities, so, they cannot afford to miss any information passed to them immediately since physical movement and interactive activities are limited [1] [13].

\section{Conclusion}

The findings of the study revealed that most respondents having MTN are more than that of people using other networks, probably because of its service availability. The study showed that those respondents who are just using $4 \mathrm{G}$ services within 1 - 6 moths are more than the other duration classes. Also, the findings showed that those having access to $4 \mathrm{G}$ Services always are more than those having access to few periods in a day. These findings therefore established obviously that due to the changes brought by COVID-19 pandemic to the daily activities, there is a shift to digital life among the subscribers. This also attests to the improvements brought by $4 \mathrm{G}$ services that helped people move to digital life to carry out their daily routines. Indeed, the COVID-19 pandemic has revealed the possible situations of using technology-based systems as the next viable alternative to physical modes of transactions.

\section{Conflicts of Interest}

The author declares no conflicts of interest regarding the publication of this paper.

\section{References}

[1] Anyamele, O.E., Okunrinboye, O. and Odukoya, A. (2020) Impact of Covid-19 on Board and General Meetings of Companies in Nigeria. A White Paper from Ajumogobia and Okeke Law Firm Specializing in Corporate and Commercial, Intellectual Property, Aviation and Energy Law.

[2] Sydow, L. (2020) The Impact of Coronavirus on the Mobile Economy. A Blog from App Annie. 
https://www.appannie.com/en/insights/market-data/coronavirus-impact-mobile-ec onomy/

[3] ITU (2020) Economic Impact of Covid 19 on Digital Infrastructure: Report of an Economic Experts Roundtable Organized by the International Telecommunication Union (ITU). GSR-20 Discussion Paper.

[4] MMAGlobal (2020) White Paper on "Covid19 Effects on Mobile and Digital Media". https://www.mmagloabl.com

[5] Connected Society (2020) GSMA White Paper on "The State of Mobile Internet Connectivity 2020". https://www.gsma.com/connected-society

[6] CAICT, GSMA and 5GAIA (2020) The GSMA and 5G Applications Industry Array (5GAIA) White Paper on "Mobile Industry Response to in China", White Paper of China Academy of Information and Communications Technology (CAICT, April 2020). https://www.caict.ac.cn

[7] Forest Interactive White Paper (2020) How the COVID-19 Pandemic Shifted Our Ways of Doing Business and Consumer Behavior Across the World. Telecommunications Industry Roundup. https://www.forest-interactive.com

[8] Rodríguez-Castelán, C., Ochoa, R.G., Lach, S. and Masaki, T. (2021) Mobile Internet Adoption in West Africa. Policy Research Working Papers, World Development Report 2021, World Bank Group, Poverty and Equity Global Practice. https://doi.org/10.1596/1813-9450-9560

[9] Maikomo, J.M, Targema, T.S. and Obun-Andy, M.K. COVID-19 and the New Normal in Developing Societies: An Appraisal of Nigerians' Adaptation to Digital Life in Public and Private Spheres. Journal of Developing Societies, 37, 246-274. https://doi.org/10.1177/0169796X21996830

[10] Adumah, C.C., Abolurin, O.O., Adekoya, A.O., Onuoha, K.M. and Adumah, L.O. (2020) Perception of Medical Students toward online Lectures during COVID-19 Outbreak in a Nigerian University. Nigerian Journal of Medicine, 29, 638-641. https://doi.org/10.4103/NJM.NJM 11320

[11] Afolabi, O., Nwobodo, M., Eze, C. and Nnadozie, U. (2020) Impact of COVID-19 Pandemic on Haemodialysis Care at a Tertiary Centre in South East Nigeria. Open Journal of Nephrology, 10, 383-387. https://doi.org/10.4236/ojneph.2020.104038

[12] KPMG Nigeria (2020) COVID-19 and the Nigerian Telecommunication, Media and Technology (TMT) Sector. White Paper, KPMG Nigeria.

[13] Guardians Newspaper (2021) Osinbajo Presides over Virtual FEC Meeting. https://guardian.ng/news/osinbajo-presides-over-virtual-fec-meeting/ 